\title{
The Relationship between Self-awareness and Learners' Performance on Different Reading Comprehension Test Types among Iranian EFL Elementary Learners
}

\author{
Mansureh Arabsarhangi \\ Department of English, Faculty of Humanities, Garmsar Branch, Islamic Azad University, Garmsar, Iran \\ Iraj Noroozi \\ Department of Language Teaching and Translation, Varamin-Pishva Branch, Islamic Azad University, Varamin, Iran
}

\begin{abstract}
This research was conducted on the basis of emotional intelligence in Goleman's model in which the correlational relationship between self-awareness as one of the variables consisted of three clusters: emotional self-awareness, accurate self-assessment, and self-confidence, and learners' performance on different reading comprehension test types including true \& false, cloze test, multiple-choice, and wh-question form, as another variable was investigated. According to the results of data analysis through the regression and ANOVA tests, the null hypotheses were rejected and the correlation of the variables was proved.
\end{abstract}

Index Terms - affective domain, Emotional Intelligence (EQ), self-awareness, reading comprehension test, EFL learners

\section{INTRODUCTION}

Despite the more emphasis on cognitive aspects of learning, it is a multi-dimensional process with three domains: cognitive, behavioral and affective. According to some researchers, "The affective domain, arguably the most complex, is rooted in the emotional life of the student" (Friedman, 2008; Friedman \& Neuman, 2001; Picard, et. al., 2004). Neuman and Friedman (2010) referred to critical components of affective domain as; values, attitudes, ethics, and selfawareness (para. 2-3). Corcoran and Tormey (n.d.), compared the Gardner's model of Multiple Intelligences to

Goleman's model of Emotional Intelligence in terms of affective domain and pointed that "work on Emotional Intelligence is more focused on the affective domain than that of Gardner" (p. 3). According to Daniel Goleman (1995), "emotional competence (or competency) is the ability to manage our emotions in a positive manner in any situation by thinking before we react, by recognizing the emotions and strengths of others, and by using this knowledge in a productive manner" (as cited in Honigsfeld \& Lupeke, 2010, p. 19). According to Honigsfeld and Lupeke (2010), "the development of the four language skills - listening, speaking, reading and writing - through meaningful, learnercentered activities may be enhanced by addressing emotional competencies as well.” (p. 19).

Some disabilities in reading comprehension success according to Logsdon (n.d.), were the written material beyond their current independent reading skill level, having limited prior knowledge about the content or having limited vocabulary knowledge, and the lack of awareness of how the reading material is structured (para. 1). Although it is obvious that reading ability especially reading comprehension is a multifactor process which required investigating the affective aspects especially learners' emotion and self-awareness as much as cognitive aspects, unfortunately there were not sufficient researches studying emotional domain. In other words, to study learning as a metalevel of human mind which according to Hannula (n.d.), considers cognition and emotion "as two sides of the same coin" (para. 5), the way ends in cognition or a little different; thinking about cognition or metacognition. To consider above studies with more emphasis on affective domain of reading comprehension, the researcher discussed the problem of present study: the relationship between learners' self-awareness and their performance on different reading comprehension test types.

Since the researcher worked on one of the emotional competencies on the basis of Goleman's Model; self-awareness with three components: emotional self-awareness, accurate self-assessment, and self-confidence, in relation to learners' performance on different reading comprehension test types, the research findings must answer these questions and reject the null hypotheses appropriately:

$\mathrm{Q}_{1}$. Is there any relationship between learners' emotional self-awareness and their performance on different reading comprehension test types among Iranian EFL elementary learners?

$\mathrm{Q}_{2}$. Is there any relationship between learners' accurate self-assessment and their performance on different reading comprehension test types among Iranian EFL elementary learners? 
$\mathrm{Q}_{3}$. Is there any relationship between learners' self-confidence and their performance on different reading comprehension test types among Iranian EFL elementary learners?

$\mathrm{H}_{0}$ 1. There is not any relationship between emotional self-awareness and learner's performance on different reading comprehension test types among Iranian EFL elementary learners.

$\mathrm{H}_{0}$ 2. There is not any relationship between accurate self-assessment and learner's performance on different reading comprehension test types among Iranian EFL elementary learners.

$\mathrm{H}_{0}$ 3. There is not any relationship between self-confidence and learner's performance on different reading comprehension test types among Iranian EFL elementary learners.

According to Rinkevičienè and Zdanytė (2002), "It is important for teachers to make learners aware of the processes involved in language learning and to help them find environments that suit their needs best" (p. 96). Rinkevičienè and Zdanyte (2002) believed that raising the learners' awareness through the processes of learning is a crucial key for the development of autonomous learning. Candy Lawson believed that "our thoughts and emotions can strongly affect motivation" (para. 8). According to Illinois State Board of Education, self-awareness "enables individuals to handle their stress, control impulses, and motivate to persevere in overcoming obstacles to goal achievement". As this study focused on self-awareness which is according to Goleman (1998), "key to realizing one's own strength and weakness" (p. 6), one of the significance of this study was emphasizing the important role of self-awareness in learners' selfassessment, as well as dealing with the relationship between learners' self-awareness and their autonomy and motivation in learning environments.

The most crucial limitations and delimitations of present study mentioned below.

1. This research is solely conducted for Iranian EFL elementary learners, and all of them are studying English in Garmsar IranMehr institute in Iran and not other institutes or other cities.

2. In this study, the researcher considered English language as foreign, instead of second language because learning English language in Iran is limited to scholastic environments like institutes and schools and is not utilized for communication in the society.

3. The researcher opted for adult learners in elementary level because they have a larger expanse of population in comparison with adolescent elementary learners in IranMehr institute (Garmsar, Iran), and also they are more capable to participate in psychological procedures, for example filling out a self-awareness questionnaire.

4. The design of this study is descriptive because the writer could not find any valid treatment for it.

5. There were a limited amount of peer reviewed articles and related to or discussed the proper aspects of selfawareness and reading comprehension. Therefore, the researcher utilized the relevant information about the variables of this study.

\section{MAIN TEXT}

\section{A. Review of the Literature}

What is emotion? According to Jenkins et al. (1998), "Emotions are central to human life; they are subjective and are made up of short-term emotions, long term moods and very long term emotional dispositions of personality" (Jenkins, Oatley \& Stein, 1998, as cited in Erasmus, 2007, p. 6).

Emotion and Learning. Hammond et al. believed that "It is critical to recognize the important link between emotions, thought, and action. Moreover, it is important to teach our students that emotions can be managed, regulated, and controlled to some degree (p. 90). According to Hammond et al., learning how to manage emotions are important in the classroom in terms of their impact on learning and on the other hand raising learners' emotional intelligence to make them successful. They also believed that teachers can support students "in developing their self-confidence by helping them learn to identify what they are thinking and how they are feeling when they make decisions" (p. 92) and they "should be aware of and sensitive to the different ways children respond to and display emotion" (p. 92).

According to Candy Lawson, "Emotions and learning occur in the brain. Learning means acquiring knowledge or skills. Learning requires thinking. Our thoughts influence how we feel. How we feel influence how we think. The connections between emotion and learning are bi-directional and complex" (para. 25). Lawson quoted from Priscilla Vail, an expert of learning that "emotion is as on-off switch to learning" (para. 3).

Emotional intelligence competencies. Self-awareness is one of these emotional competencies which consisted of three components: emotional awareness, accurate self-assessment, and self-confidence. Boyatzis, Goleman, and Rhee (1999) believed that "The organization of the competencies under the various constructs is not random; they appear in synergistic clusters or groupings that support and facilitate each other" (as cited in Stys \& L. Brown, p. 15). According to Honigsfeld and Lupeke (2010), "The aligned summary of three theoretical constructs related to emotional intelligence is presented in Table I" (p. 19). 
TABLE I.

ALIGNMENT OF THEORIES ON EMOTIONAL COMPETENCE

\begin{tabular}{|c|c|c|}
\hline \multirow[t]{2}{*}{$\begin{array}{l}\text { Gardner's Multiple } \\
\text { Intelligences } \\
\text { ( } 2 \text { out of 9) } \\
\text { Intrapersonal Intelligence } \\
\text { Understanding oneself and having } \\
\text { insights into one's own thoughts, } \\
\text { actions and emotions ( self- } \\
\text { understanding) }\end{array}$} & $\begin{array}{l}\text { Goleman's } \\
\text { Emotional Competencies } \\
\text { Self Awareness (Recognition): } \\
\text { Developing emotional self } \\
\text { awareness, accurate self } \\
\text { assessment, self confidence }\end{array}$ & $\begin{array}{l}\text { Six Seconds } \\
\text { Self Science } \\
\text { Know Yourself } \\
\text { Legitimizing self knowledge as } \\
\text { subject matter } \\
\text { Becoming aware of multiple } \\
\text { feelings }\end{array}$ \\
\hline & $\begin{array}{l}\text { Self Management } \\
\text { (Regulation): } \\
\text { Developing self control, trustworthiness, } \\
\text { conscientiousness, } \\
\text { adaptability, achievement drive, } \\
\text { initiative }\end{array}$ & $\begin{array}{l}\text { Choose Yourself } \\
\text { Developing a trusting attitude } \\
\text { towards others. } \\
\text { Enhancing self-esteem }\end{array}$ \\
\hline \multirow[t]{2}{*}{$\begin{array}{l}\text { Interpersonal Intelligence } \\
\text { Understanding of others and one's } \\
\text { relationships to others - social } \\
\text { skills }\end{array}$} & $\begin{array}{l}\text { Social Awareness } \\
\text { (Recognition): Showing empathy, } \\
\text { service orientation, organizational } \\
\text { awareness }\end{array}$ & \\
\hline & $\begin{array}{l}\text { Relationship Management } \\
\text { (Regulation): Developing others, } \\
\text { influence, communication, } \\
\text { conflict management, } \\
\text { leadership, change catalyst, } \\
\text { building bonds, teamwork and } \\
\text { collaboration }\end{array}$ & $\begin{array}{l}\text { Give Yourself } \\
\text { Disclosing thoughts and feeling }\end{array}$ \\
\hline
\end{tabular}

Self-awareness and its components. Daniel Goleman, maintained that self-awareness (i.e., knowing one's emotions) is foundational to emotional intelligence and described it as being "aware of both our mood and our thoughts about that mood." and consisted of three components: emotional self-awareness, accurate self-assessment, and self-confidence.

Emotional self-awareness, according to Goleman (1998) defined as: "Recognizing one's emotions and their effects", accurate self-assessment means "Knowing one's strengths and limits", and self-confidence described as: "Sureness about one's self-worth and capabilities". According to Grayson (n.d.) "Emotional self-awareness is the ability to recognize one's feelings. It is not only the ability to be aware of one's feelings and emotions, but also to differentiate between them, to know what one is feeling and why, and to know what caused the feelings" (p. 6).

Anderson and Lux (2004) argued that "an adequate account of autonomy must include a distinct requirement of accurate self-assessment, which has been largely ignored in the philosophical focus on agents' ability to evaluate the desirability of acting on certain impulses or values" (p. 279). According to Anderson and Lux (2004) "there is a distinct requirement of accurate self-assessment, which is connected more with executing a task than with evaluating its desirability" (p. 279).

According to Hargreaves ( n.d.), "To become effective learners, young people need to develop a strong sense of selfworth and confidence in their abilities. They need to learn to take responsibility for their own learning and performance, and demonstrate persistence and resilience in the face of obstacles or setbacks (para. 32).

Reading comprehension test types. According to R. Day and Park (2005), there are six different types of comprehension: Literal comprehension, Reorganization, Inference, Prediction, Evaluation, and Personal response.

R. Day and Park (2005) believed that there are five forms of reading comprehension questions: Yes/no questions, Alternative questions, True or false, Wh- questions, Multiple-choice. According to Fletcher (2006), "the measurement issues are complicated, reflecting the complex, multidimensional nature of reading comprehension" (p. 323).

Self-Awareness and Reading Comprehension. Regarding these studies, the researcher administered four different types of reading comprehension tests to a group of Iranian EFL elementary learners. The reading comprehension tests of this study consisted of: Multiple-choice, True or False, Cloze- test, and Wh-question. Goleman (1998) referred to the relationship between self-awareness and performance and claimed that "The first of the three Self-Awareness competencies, Emotional Self-Awareness, reflects the importance of recognizing one's own feelings and how they affect one's performance" (p. 6). According to Alexander and Jetton (2000); Biancarosa and Snow (2004), "Reading ability is multidimensional, influenced by many cognitive, affective, physiological, psychological, social, and emotional factors (as cited in Yribarren, n.d., p. 1). Some researchers believed that good readers have confidence in their ability to read and understand what they read and they have a sense of themselves as good readers and enjoy reading (Ylvisker, Hibbard \& Feeney, n.d.). Barton (Sep., 1996) in terms of the relationship between reading and emotional awareness claimed that "Readers learn about emotions from stories and emotional awareness helps readers understand stories." Hisken (2011) regarding the role of self-esteem and self-confidence in reading ability believed that:

Students with low self-esteem tend to have lower reading abilities because they do not feel confident enough to take risks in their reading. They are not confident enough in themselves or their ability to try new genres, authors, or types of reading materials. (p. 7)

\section{B. Material and Method}


Participants. The subjects of this investigation were English language elementary learners. The participants of the study were 50 adult Elementary Iranian EFL learners at the age of 15 to 30 selected from English language learners of IranMehr institute (Garmsar, Iran).

\section{Instrumentation}

- Placement test. The English Unlimited placement test (Written test, Cambridge University Press, 2010) consisted of 120 multiple-choice questions, 20 at each level from Starter to Advanced was administered to 70 learners at the age of 15 to 30 who registered in adult elementary level of IranMehr Institute. 50 subjects with appropriate scores (16-35), were selected as participants by the researcher.

- Self-awareness questionnaire. The self-awareness questionnaire consisted of 39 close questions (13 questions for each cluster) adapted from online questionnaires developed by some researchers (Silver \& Claret, B. Davies, Downing, T. Ziv, and self-analysis questionnaire retrieved from www.evh.org.uk) that translated to Persian and must be answered by the respondents. All measures in this self-awareness questionnaire used a 5point Likert scale from $0=$ Never to $5=$ Always.

- Reading comprehension tests. The researcher administered four different reading comprehension test types: Multiple-choice, True or False, Cloze- test, and Wh-question. These tests, each one consisted of 20 questions, adapted from online standardized tests developed by some organizations (university of Victoria: English Language Centre, Cambridge ESOL Reading Comprehension Exercise: Key Test of English (KET), English File 1, extra reading material: Oxford University Press).

Procedure. Firstly, the English Unlimited placement test was given to 70 learners who registered in IranMehr Institute (Garmsar, Iran) and 50 elementary subjects at the age of 15-30 and with average scores of 16-35 were selected. After homogenizing the subjects, and estimating the reliability of the self-awareness questionnaire and four different reading comprehension test types by piloting the tests with 10 elementary subjects, the researcher conducted the Persian self-awareness questionnaire and four different reading comprehension tests to the 50 participants. Finally, the data gathered from these two scores (reading comprehension tests and self-awareness questionnaire) were analyzed for each person.

Design. The design of this study was quantitative and descriptive and a correlational relationship between variables instead of causal relationshipwas investigated. Since the researcher worked on one of the competencies of EQ in Goleman's model, the method of this research was ex post facto.

\section{Results and Discussion}

Testing Assumptions. The research questions raised in this study have been analyzed through the regression analysis, thus the assumptions of interval data, normality, linearity and homoscedasticity should be met (Field, 2009). The data are measured on an interval scale. The assumption of normality is also met. The ratios of skewness and kurtosis over their respective standard errors are within the ranges of $+/-1.96$ (Filed, 2009).

TABLE II.

TESTING NORMALITY ASSUMPTION

\begin{tabular}{|c|c|c|c|c|c|c|c|}
\hline & $\mathbf{N}$ & Skewness & & & Kurtosis & & \\
\hline & Statistic & Statistic & Std. Error & Ratio & Statistic & Std. Error & Ratio \\
\hline$\overline{\mathrm{SC}}$ & 50 & -.354 & .337 & -1.050 & -.495 & .662 & -0.748 \\
\hline ASA & 50 & -.320 & .337 & -0.950 & .948 & .662 & 1.432 \\
\hline ESA & 50 & .239 & .337 & 0.709 & .255 & .662 & 0.385 \\
\hline Cloze & 50 & -.452 & .337 & -1.341 & -.605 & .662 & -0.914 \\
\hline Wh-question & 50 & -.196 & .337 & -0.582 & -.920 & .662 & -1.390 \\
\hline TF & 50 & -.178 & .337 & -0.528 & -.137 & .662 & -0.207 \\
\hline MC & 50 & -.761 & .337 & -2.258 & -.275 & .662 & -0.415 \\
\hline
\end{tabular}

According to the regression model, ANOVA test (Table II \& Table III), and the existent assumption of linearity and homoscedasticity(Scatter Plot $1 \& 2$ ), learners' scores on the Cloze test could predict about 50 percent of their emotional self-awareness $\left(\mathrm{R}=.70, \mathrm{R}^{2}=.49\right)$, but the other types of reading comprehension tests were not entered into the regression model and the assumptions.

TABLE III.

MODEL SUMMARY EMOTIONAL SELF-AWARENESS THROUGH READING COMPREHENSION TESTS

\begin{tabular}{lllll}
\hline Model & R & R Square & Adjusted R Square & Std. Error of the Estimate \\
\hline $\mathbf{1}$ & $.702^{\mathrm{a}}$ & .492 & .482 & $\mathbf{6 . 1 6 2}$ \\
\hline a. Predictors: (Constant), Cloze & & \\
\hline b. Dependent Variable: ESA & & \\
\hline
\end{tabular}


TABLE IV.

ANOVA TEST OF SIGNIFICANCE OF REGRESSION MODEL EMOTIONAL SELF-AWARENESS THROUGH READING COMPREHENSION

\begin{tabular}{lllllll}
\hline Model & & Sum of Squares & Df & Mean Square & F & Sig. \\
\hline \multirow{3}{*}{1} & Regression & 1767.735 & 1 & 1767.735 & 46.563 & $\mathbf{. 0 0}^{\text {b }}$ \\
\cline { 2 - 7 } & Residual & 1822.285 & 48 & 37.964 & & \\
\cline { 2 - 7 } & Total & $\mathbf{3 5 9 0 . 0 2 0}$ & 49 & & & \\
\hline
\end{tabular}

a. Dependent Variable: ESA

b. Predictors: (Constant), Cloze

Normal P-P Plot of Regression Standardized Residual

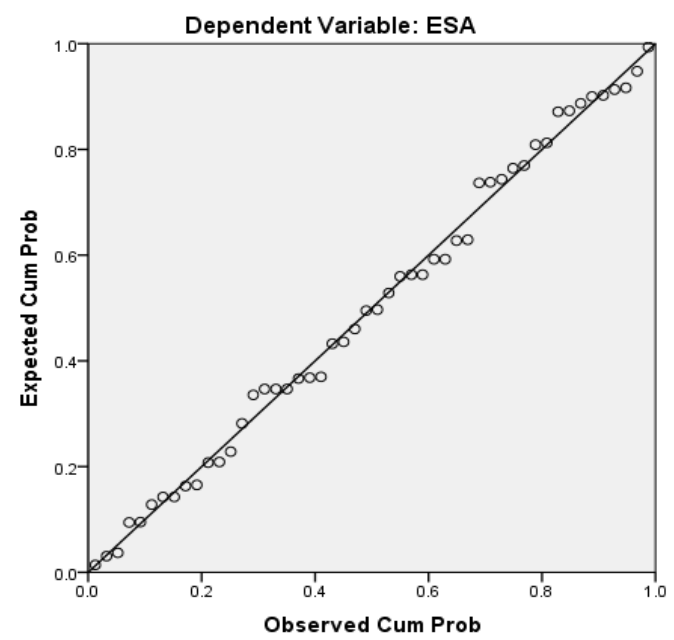

Q-Q Plot 1. Emotional self-awareness through reading comprehension tests.

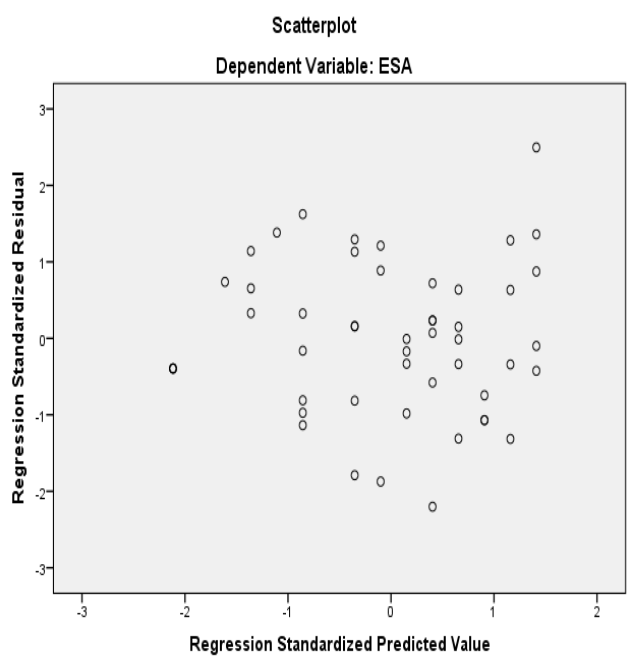

Scatter Plot 2. Assumption of homoscedasticity self-awareness through reading comprehension tests.

As displayed in Table V and Table VI, the MC test, TF, and Cloze test, in order, were the best predictors of learners' accurate self-assessment, in other words, MC, TF and Cloze together could predict 73 percent of learners' accurate selfassessment but the assumptions of linearity and homoscedasticity were not met (Scatter Plot $3 \& 4$ ), which means the results can only be applied to the population from which the sample is selected. In research question 2, Wh-q was not entered into the regression model.

TABLE V.

\begin{tabular}{lllll}
\multicolumn{3}{l}{ MODEL SUMMARY ACCURATE SELF-ASSESSMENT THROUGH READING COMPREHENSION ESTS } \\
\cline { 2 - 5 } Model & $\mathbf{R}$ & R Square & Adjusted R Square & $\begin{array}{l}\text { Std. Error of the } \\
\text { Estimate }\end{array}$ \\
\hline $\mathbf{1}$ & $\mathbf{. 7 7 8}^{\mathrm{a}}$ & $\mathbf{. 6 0 5}$ & $\mathbf{. 5 9 7}$ & $\mathbf{5 . 5 1 2}$ \\
\hline $\mathbf{2}$ & $\mathbf{. 8 4 2}^{\mathbf{b}}$ & $\mathbf{. 7 0 9}$ & $\mathbf{. 6 9 6}$ & $\mathbf{4 . 7 8 5}$ \\
\hline $\mathbf{3}$ & $\mathbf{. 8 5 8}^{\mathbf{c}}$ & $\mathbf{. 7 3 6}$ & $\mathbf{. 7 1 9}$ & $\mathbf{4 . 6 0 3}$ \\
\hline
\end{tabular}

a. Predictors: (Constant), MC

b. Predictors: (Constant), MC, TF

c. Predictors: (Constant), MC, TF, Cloze

d. Dependent Variable: ASA 
TABLE VI.

ANOVA TEST OF SIGNIFICANCE OF REGRESSION MODEL ACCURATE SELF-ASSESSMENT THROUGH READING COMPREHENSION TESTS

\begin{tabular}{|c|c|c|c|c|c|c|}
\hline Model & & Sum of Squares & df & Mean Square & $\mathbf{F}$ & Sig. \\
\hline & Regression & 2235.312 & 1 & 2235.312 & 73.572 & $.000^{b}$ \\
\hline \multirow[t]{3}{*}{1} & Residual & 1458.368 & 48 & 30.383 & & \\
\hline & Total & 3693.680 & 49 & & & \\
\hline & Regression & 2617.735 & 2 & 1308.867 & $\mathbf{5 7 . 1 7 5}$ & $.000^{\mathrm{c}}$ \\
\hline \multirow[t]{3}{*}{2} & Residual & 1075.945 & 47 & 22.892 & & \\
\hline & Total & 3693.680 & 49 & & & \\
\hline & Regression & 2718.955 & 3 & 906.318 & 42.772 & $.000^{d}$ \\
\hline \multirow[t]{2}{*}{3} & Residual & 974.725 & 46 & 21.190 & & \\
\hline & Total & 3693.680 & 49 & & & \\
\hline \multicolumn{7}{|c|}{ a. Dependent Variable: ASA } \\
\hline \multicolumn{7}{|c|}{ b. Predictors: (Constant), MC } \\
\hline \multicolumn{7}{|c|}{$\begin{array}{l}\text { c. Predictors: (Constant), MC, TF } \\
\end{array}$} \\
\hline
\end{tabular}

Normal P-P Plot of Regression Standardized Residual

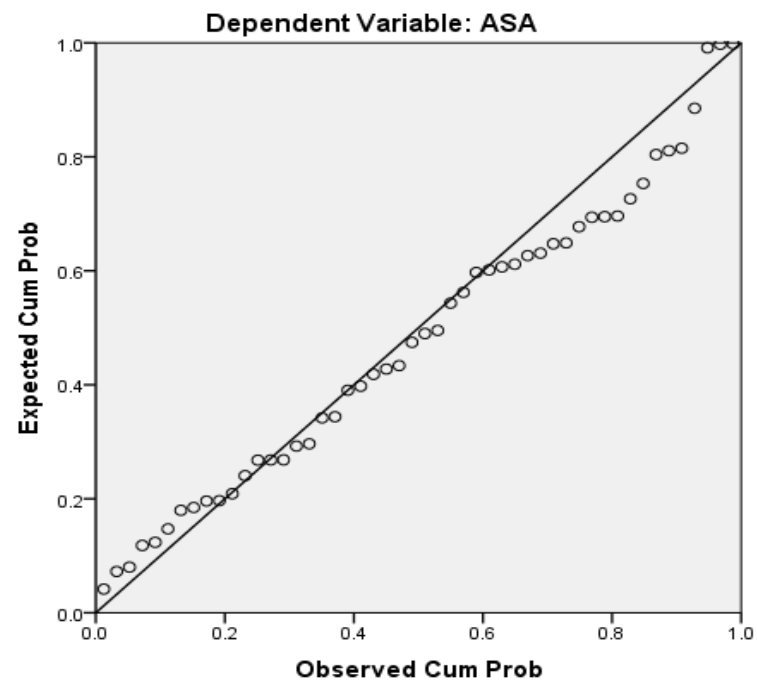

Q-Q Plot 3. Accurate self-assessment through reading comprehension tests.

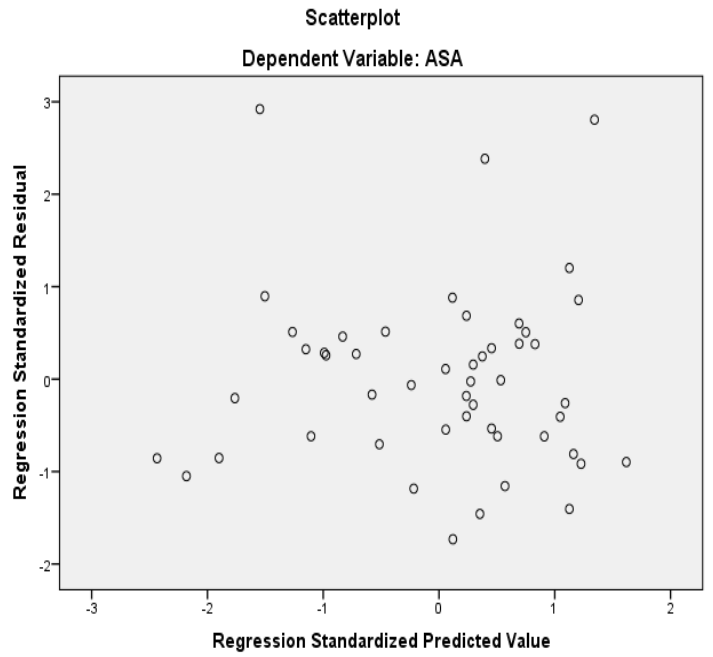

Scatter Plot 4. Assumption of homoscedasticity accurate self-assessment through reading comprehension tests.

According to regression model and ANOVA test (Table VII \& Table VIII), learners' scores on Wh-q, TF, and MC tests, in order, were the best predictors of their self-confidence, in other words, MC, TF and Cloze together could predict 73 percent of learners' self-confidence, and Cloze test was the only excluded variable. The assumptions of linearity were not met which means the results can only be applied to the population from which the sample is selected but the assumptions of homoscedasticity were met (Scatter Plot $5 \& 6$ ). 
TABLE VII

MODEL SUMMARY SELF-CONFIDENCE THROUGH READING COMPREHENSION TESTS

\begin{tabular}{|c|c|c|c|c|}
\hline Model & $\mathbf{R}$ & R Square & Adjusted R Square & $\begin{array}{l}\text { Std. Error of the } \\
\text { Estimate }\end{array}$ \\
\hline 1 & $.777^{\mathrm{a}}$ & .604 & .596 & 6.490 \\
\hline 2 & $.838^{b}$ & .702 & .689 & 5.695 \\
\hline 3 & $.857^{\mathrm{c}}$ & .734 & .717 & 5.431 \\
\hline \multicolumn{5}{|c|}{ a. Predictors: (Constant), Whq } \\
\hline \multicolumn{5}{|c|}{ b. Predictors: (Constant), Whq, TF } \\
\hline \multirow{2}{*}{\multicolumn{5}{|c|}{ c. Predictors: (Constant), Whq, TF, MC }} \\
\hline d. Depen & & & & \\
\hline
\end{tabular}

TABLE VIII.

ANOVA TEST OF SIGNIFICANCE OF REGRESSION MODEL SELF-CONFIDENCE THROUGH READING COMPREHENSION TESTS

\begin{tabular}{|c|c|c|c|c|c|c|}
\hline Model & & Sum of Squares & df & Mean Square & $\mathbf{F}$ & Sig. \\
\hline \multirow{3}{*}{1} & Regression & 3088.444 & 1 & 3088.444 & 73.332 & $.000^{\mathrm{b}}$ \\
\hline & Residual & 2021.556 & 48 & 42.116 & & \\
\hline & Total & 5110.000 & 49 & & & \\
\hline \multirow{3}{*}{2} & Regression & 3585.887 & 2 & 1792.943 & 55.290 & $.000^{\mathrm{c}}$ \\
\hline & Residual & 1524.113 & 47 & 32.428 & & \\
\hline & Total & 5110.000 & 49 & & & \\
\hline \multirow{3}{*}{3} & Regression & 3753.043 & 3 & $\mathbf{1 2 5 1 . 0 1 4}$ & 42.409 & $.000^{\mathrm{d}}$ \\
\hline & Residual & 1356.957 & 46 & 29.499 & & \\
\hline & Total & 5110.000 & 49 & & & \\
\hline \multicolumn{7}{|c|}{ a. Dependent Variable: SC } \\
\hline \multicolumn{7}{|c|}{ b. Predictors: (Constant), Whq } \\
\hline \multicolumn{7}{|c|}{ c. Predictors: (Constant), Whq, TF } \\
\hline
\end{tabular}

Normal P-P Plot of Regression Standardized Residual

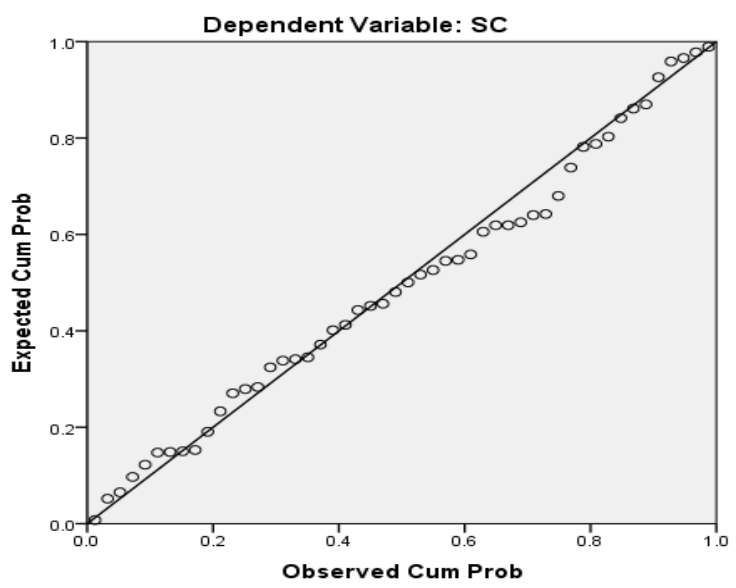

Q-Q Plot 5. Self-confidence through reading comprehension tests.

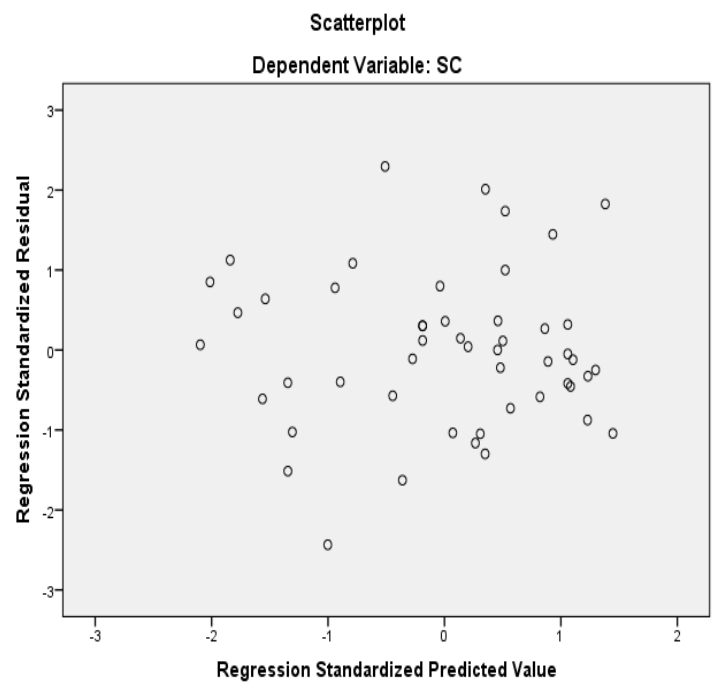

Scatter Plot 6. Assumption of homoscedasticity self-confidence through reading comprehension tests. 
Reliability Indices. The K-R21 reliability indices of the tests employed in this study are displayed in this study. They range from a high of .97 for the cloze test to a low of .56 for the MC test (Table IX).

TABLE IX.

K-R 21 RELIABILITY INDICES

\begin{tabular}{lllll}
\hline & N & Mean & Variance & K-R21 \\
\hline Self-Confidence & 50 & 43.00 & 104.286 & 0.96 \\
\hline Accurate Self-Assessment & 50 & 42.08 & 75.381 & 0.93 \\
\hline Emotional Self-Awareness & 50 & 41.14 & 73.266 & 0.92 \\
\hline Cloze & 50 & 13.40 & 15.755 & 0.97 \\
\hline Whq & 50 & 13.64 & 7.092 & 0.88 \\
\hline TF & 50 & 12.54 & 6.539 & 0.73 \\
\hline MC & 50 & 14.34 & $\mathbf{8 . 6 3 7}$ & $\mathbf{0 . 5 6}$ \\
\hline
\end{tabular}

\section{CONCLUSIONS}

According to the results of data analysis which were drawn from this study, it can be claimed that the findings were in agreement with theoretical framework of this study which was on the basis of Goleman's model of EQ (1995), and because of focusing on self-awareness as one of the important component of Goleman's theory and its association with reading skill, the present study might help to extend the previous studies in this domain. Also it might be claimed that the findings of this study predicted and indicated that there was a correlational relationship between self-awareness and reading comprehension. However, there were some exceptions, such as lack of assumptions of linearity and homoscedasticity in data analysis of research question 2 and 3 which according to Field (2005) means that the regression model can be perfectly used to draw conclusions about the data gathered from the present sample and it cannot be generalized to other populations.

Despite the previous studies which dealt more with all of the competencies of EQ as a whole concept, in present study, the focus is more on self-awareness competency of EQ in Goleman's model and investigating its relationship with reading comprehension. In present study, self-awareness as a personal and emotional competence was described in terms of affective domain of learning rather than cognitive domain. The results might lead to an appropriate example of association between learners' competence (self-awareness) and their performance through learning English language. Since this study focused on self-awareness which is according to Goleman (1998) a key to becoming aware of one's own strength and weakness, another benefit of this study might be for learners to accurately assess their own performance and recognize their abilities and disabilities through learning process. The crucial aim of this study was to discuss the importance of the role of learners' self-awareness in development of autonomous learning, since according to Kohonen (1991), "Raising the awareness of one's own learning and gaining an understanding of the processes involved is thus another important key for the development of autonomous learning". One of the best implication of this research is for teachers to support the learners' emotions and feelings in addition to improve their cognitive ability, in order to make a motivational environment of learning in their classes.

Suggestions for Further Research

Regarding the result of this study which supported the purpose of investigating the relationship between selfawareness and learners' performance on different reading comprehension test types, according to findings which showed that there is a relationship between variables of the study, and considering the limitations of present study, the researcher suggested some related topics for future research directions.

1. According to this study, it may be claimed that learners' self-awareness is related to their performance in reading comprehension tests. It seems that more researches are required to investigating the significant effect of different levels of self-awareness on learners' performance on reading comprehension tests.

2. The researcher proposes the investigation of the role of emotional self-awareness in reading comprehension of different genres of short stories.

3. The procedures of this study can be utilized in other settings such as universities and schools.

4. Replication of this study can be done for Iranian EFL learners at different levels of language proficiency.

5. The line of this research may be followed on the role of self-awareness in speaking or writing tasks, because this paper was done only in reading comprehension tests.

6. The researcher calls for implementing another study with larger numbers of participants who include genders, males, and females. 


\begin{tabular}{|c|c|c|c|c|c|c|c|}
\hline & Emotional Self-Awareness- & $\begin{array}{l}\text { Always } \\
=5\end{array}$ & $\begin{array}{l}\text { Almost } \\
\text { Always }=4\end{array}$ & $\begin{array}{l}\text { Often } \\
=3\end{array}$ & $\begin{array}{l}\text { Sometimes } \\
=2\end{array}$ & $\begin{array}{l}\text { Rarely } \\
=1\end{array}$ & $\begin{array}{l}\text { Never } \\
=0\end{array}$ \\
\hline 1 & I always know which emotions I am feeling and why & & & & & & \\
\hline 2 & $\begin{array}{l}\text { I realize the links between my feelings and what I think, do, and } \\
\text { say }\end{array}$ & & & & & & \\
\hline 3 & I recognize how my feelings affect my performance & & & & & & \\
\hline 4 & I can recognize the situations that trigger my emotions & & & & & & \\
\hline 5 & I have a good understanding of what are my values and my goals & & & & & & \\
\hline 6 & I am aware of situations that cause me to think negatively & & & & & & \\
\hline 7 & I am aware of the impact my moods have on other people & & & & & & \\
\hline 8 & I am able to express my emotions in an appropriate manner & & & & & & \\
\hline 9 & I do not lose control when I am angry & & & & & & \\
\hline 10 & I always know whether or not I am happy & & & & & & \\
\hline 11 & I can say when I get upset & & & & & & \\
\hline 12 & I accept my emotions as my own & & & & & & \\
\hline 13 & I am realistic about myself and others & & & & & & \\
\hline & Accurate Self-Assessment & & & & & & \\
\hline 14 & I am aware of my strengths and weaknesses & & & & & & \\
\hline 15 & I am reflective and try to learn from experience & & & & & & \\
\hline 16 & $\begin{array}{l}\text { I am open to candid feedback, new perspectives, continuous } \\
\text { learning, and self-development }\end{array}$ & & & & & & \\
\hline 17 & I am able to show a sense of humour and perspective about myself & & & & & & \\
\hline 18 & $\begin{array}{l}\text { I am not defensive in receiving new information or perspectives } \\
\text { about myself }\end{array}$ & & & & & & \\
\hline 19 & $\begin{array}{l}\text { I compensates for my limitations by working with others with the } \\
\text { necessary strengths }\end{array}$ & & & & & & \\
\hline 20 & $\begin{array}{l}\text { I make career choices to leverage opportunities to learn new things } \\
\text { or broaden my Experiences }\end{array}$ & & & & & & \\
\hline 21 & I seek out opportunities to broaden my repertoire of capabilities & & & & & & \\
\hline 22 & when I encounter a challenging problem, I try to solve it by myself & & & & & & \\
\hline 23 & I solicit honest critiques & & & & & & \\
\hline 24 & I can set personal goals and monitor progress toward these goals & & & & & & \\
\hline 25 & $\begin{array}{l}\text { I am open to ongoing growth and development by learning from } \\
\text { my mistakes and experiences }\end{array}$ & & & & & & \\
\hline 26 & I am introspective & & & & & & \\
\hline & Self-Confidence & & & & & & \\
\hline 27 & I feel confident to work without the need for direct supervision & & & & & & \\
\hline 28 & $\begin{array}{l}\text { I believes myself to be among the most capable for a job and likely } \\
\text { to succeed }\end{array}$ & & & & & & \\
\hline 29 & $\begin{array}{l}\text { I present myself in an assured, forceful, impressive and } \\
\text { unhesitating manner }\end{array}$ & & & & & & \\
\hline 30 & $\begin{array}{l}\text { I assume significant personal or professional risk to accomplish } \\
\text { important goals } \\
\text { (e.g. challenging powerful others with an unpopular point of view) }\end{array}$ & & & & & & \\
\hline 31 & $\begin{array}{l}\text { I speak out for a course of action I believe in even when others } \\
\text { disagree }\end{array}$ & & & & & & \\
\hline 32 & $\begin{array}{l}\text { I can voice views that are unpopular and go out on a limb for what } \\
\text { is right }\end{array}$ & & & & & & \\
\hline 33 & $\begin{array}{l}\text { I am decisive, and able to make sound decisions despite } \\
\text { uncertainties and pressures }\end{array}$ & & & & & & \\
\hline 34 & $\begin{array}{l}\text { I consider myself an effective person, capable of taking on } \\
\text { challenges and master new tasks }\end{array}$ & & & & & & \\
\hline 35 & I have personal presence (i.e. I stand out in a group) & & & & & & \\
\hline 36 & I am the best student in my reading class I appreciate what I have & & & & & & \\
\hline 37 & I stick to my principles & & & & & & \\
\hline 38 & I do not worry about what others think about me & & & & & & \\
\hline 39 & I speak positively about myself & & & & & & \\
\hline
\end{tabular}

\section{ACKNOWLEDGEMENT}

Foremost, I would like to express my sincere gratitude to my dear supervisor professor, Dr. Iraj Noroozi, for his support and guidance, patience and encouragement, and immense knowledge throughout my thesis.

My sincere appreciation also goes to my dear and honorable advisor professor, Dr. Ahmad Mohseni for his careful and precise attention to this piece of work.

I am extremely grateful to the staff and all the teachers of Iran Mehr institute, especially, Mrs Ghezlou for their help in sample selection and data collection of this study. 


\section{REFERENCES}

[1] Alexander, P. A., \& Jetton, T. J. (2000). Learning from text: A multidimensional and developmental perspective. In M. L. Kamil, P. B. Mosenthal, P. D. Pearson, \& R. Barr (Eds.), Handbook of reading research (Vol. 3, pp. 285-310). Mahwah, NJ: Lawrence Erlbaum Associates.

[2] Andereson, J. \& Lux, W. (2004). Knowing Your Own Strength: Accurate Self-Assessment as Requirement for Personal Autonomy. PPP / Vol. 11, NO. 4 / December 2004. () 2005 by The Johns Hopkins University Press.

[3] Barton, James, (Sep., 1996). Interpreting Character Emotions for Literature Comprehension. Journal of Adolescent \& Adult Literacy. Vol. 40, No. 1 (Sep., 1996), pp. 22-28. Published by: International Reading Association. Article Stable URL: http://www.jstor.org/stable/4001210810.2307/40012108.

[4] Biancarosa, G., \& Snow, C. (2004). Reading next: A vision for action and research in middle and high school literacy. Washington, DC: Alliance for Education.

[5] Boyatzis, R. E., Goleman, D., \& Rhee, K. (1999). Clustering competence in emotional intelligence: Insights from the Emotional Competence Inventory (ECI). In Bar-On, R. \& J.D. Parker (Ed's.), Handbook of Emotional Intelligence. San Francisco: Jossey-Bass.

[6] Corcoran, R. \& Tormey, R. (n.d.). Understanding Emotional Competencies Through Development Education in Teacher Education. Department of Education and Professional Studies, University of Limerick, Plassey Technological Park, Limerick. Retrieved on 2013, July 10 from http://www.nuigalway.ie/dern/.../41_roisin_corcoran_and_roland_tormey.pdf

[7] Darling-Hammond, L.; Orcutt, S., Strobel, K., Kirsch, E., Lit, I., Martin, D., With Contributions From James Comer, M.D. Feelings Count: Emotions and Learning. Learning classroom, Session 5. Stanford University School of Education.

[8] Day, R. R. \& Park, J. (2005). Developing reading comprehension questions. Reading in a Foreign Language Volume 17, No. 1, April 2005. ISSN 1539-0578.

[9] Erasmus, C. P. (March 2007). The role of Emotional intelligent in the adaptation of adolescent boys in a private school. Master of education dissertation. University of South Africa. Retrieved on 2013, January 22 from http://www.Uir. unisa.ac.za/bitstream/10500/2203/1/dissertation.pdf

[10] Field, A. (2009). Discovering Statistics Using SPSS. ${ }^{\text {rd }}$ ed. SAGE. London.

[11] Friedman, B. D. (2008). How to teach effectively. Chicago, Ill. Lyceum Books, Inc.

[12] Friedman, B. D. \& Neuman, K.. M. (2001). Learning plans: A tool for forging allegiances in social work education.” Journal of Teaching and Learning in Social Work, 21(3/4), $123-138$.

[13] Goleman, D. (1995). Emotional intelligence: Why it can matter more than IQ. NewYork Bantam Books.

[14] Goleman, D. (1998). The Emotionally Intelligent Workplace: An EI-Based Theory of Performance (Chapter Three). Cherniss C. \& Goleman D. (Eds.). Consortium for Research on Emotional Intelligence in Organizations. Retrieved from http://www.eiconsortium.org.

[15] Fletcher, J. M. (2006). Measuring Reading Comprehension. Department of Psychology University of Houston. SCIENTIFIC STUDIES OF READING, 10(3), 323-330 Copyright () 2006, Lawrence Erlbaum Associates, Inc.

[16] Grayson, R. (n.d.). Emotional Intelligence: A Summary. Retrieved on 2013 from http://www.visionrealization.com.

[17] Hannula, M. S. (n.d.).The Metalevel of Cognition-Emotion Interaction. University of Turkumarkku.hannula@zpg.fiAddress: Kuusikallionkuja 4 C 3302210 Espoo.

[18] Hargreaves, A. (n.d.).Emotional intelligence: Research summaries. Retrieved on 2013, March 2 from http://www.journeytoexcellence.org.uk/resourcesandcpd/research/summaries/rsemoti.

[19] Hisken, L. J. (December, 2011). The Correlation Between Self-esteem and Student Reading Ability, Reading Level, and Academic Achievement [Abstract]. University of Central Missouri.

[20] Honigsfeld, A. \& Lupeke, S. (2010). Share the value of exploring emotions while teaching English: Emotional Reactions. Language Magazine. Retrieved on 2012, December 17 from http://www.languagemagazine.com.

[21] Illinois State Board of Education (ISBE). Illinois Learning Standards: Social/Emotional Learning (SEL): Goal 1- Develop selfawareness and self- management skills to achieve school and life success (PDF). Retrieved on 2013 from http://www.isb.net/ils/social-emotional/standards.htm.

[22] Jenkins, K.; Oatley, K.; Stein, N. L. (1998). Human Emotions: A Reader Introduction. Malden, Massachutes: Blackwell.

[23] Lawson, C. (n.d.).The Connections Between Emotion and Learning. Retrieved on 2013 from http://cdl.org/resourcelibraryarticles/connect-emotions.php.

[24] Logsdon, A. (n.d.). Understanding Reading Comprehension Problems. Learn about Reading Comprehension Problems and $\begin{array}{llllll}\text { Strategies to } & \text { Improve. } & \text { Retrieved } & \text { 2013, } & \text { April } & 24\end{array}$ http://learningdisabilities.about.com/od/readingstrategies/a/Understanding-Reading-C.

[25] McNair, C. L. (2011). A Comparison of the Effect of Two Strategies on Adolescent Reading Comprehension and the Relationship between Reading Ability and Reader Self-Perception (ProQuest Dissertation \& Theses). Retrieved on 2013 from http://www.udini.proquest.com.

[26] Neuman, K. M. \& Friedman, B. D (2010). Affective Learning: A Taxonomy For Teaching Social Work Values. Journal of Social Work Values and Ethics, Volume 7, Number 2 (Fall 2010). Copyright 2010, White Hat Communications. Retrieved on 2013, April 3 from http://www.socialworker.com/jswve.

[27] Picard, R. W., Papert, S., Bender, W., Blumberg, B., Breazeal, C., Cavallo, D., Machover, T., Resnick, M., Roy, D. \& Strohecker, D. Affective learning - A manifesto. (2001). Technology Journal, 22(4), 253- 269.

[28] Rinkeviciene, I. \& Zdanyte, J. (2001). Changing Roles in Language Learning. Current Issues of Cultural and Spiritual Stys, Y. \& L. Brown, S. (March 2012). A Review of the Emotional Intelligence Literature and Implications for Corrections. Research Branch Correctional Service of Canada. Development. Research papers. Akademija. 
[29] Talebinejad, M. R. \& Rezai Fard, Z. (September 2012). Islamic Azad University, Shahreza Branch, Isfahan, Iran. Journal of Language Teaching and Research, Vol. 3, No. 5, pp. 844- 850, September 2012 (C) 2012 ACADEMY PUBLISHER Manufactured in Finland.

[30] Ylvisaker, M.; Hibbard, M. \& Feeney, T. (n.d.). Tutorial: Reading Comprehension. Retrieved on 2013 from http://www.projectlearnet.org/tutorials/reading_comprehension.html.

[31] Yribarren, L. (n.d.). Adolescent Reader's Self Perceptions of Affective Factors Related to Performance on Standardized Test. (dissertation). Retrieved on 2013 from http://www. udini.proquest.com.

Mansureh Arabsarhangi is an MA graduated in ELT major from Garmsar (Semnan) Azad university. She has taught English courses in Damavand (Tehran), and Garmsar (Semnan) institutes of Iran. Her major interests are psycholinguistics and sociolinguistics.

Iraj Noroozi is an associate professor in TEFL graduated from the Islamic Azad University, Science and Research Branch. He has been the head of the English department for two consecutive years and has also been the head of the faculty of the literature and humanities at the Islamic Azad University, Varamin-Pishva Branch for three years. He has published six course books under the title of general and specialized English for the university students and has developed twenty articles in the realm of language learning and teaching. He has conducted four research projects thus far as well. He has also the command of the French and German languages. 